\title{
Terrestrial Laser Scanning (TLS) data for the analysis of coastal tuff cliff retreat: application to Coroglio cliff, Naples, Italy
}

\author{
Teresa Caputo $^{1,}$, Ermanno Marino ${ }^{2}$, Fabio Matano $^{3}$, Renato Somma $^{1}$, Claudia Troise $^{1}$ \\ and Giuseppe De Natale ${ }^{1}$ \\ ${ }^{1}$ Istituto Nazionale di Geofisica e Vulcanologia, Sezione di Napoli Osservatorio Vesuviano, Napoli, Italy \\ 2 Stage srl, Marcianise, Italy \\ ${ }^{3}$ Consiglio Nazionale delle Ricerche (CNR), Istituto per l'Ambiente Marino Costiero, Napoli, Italy
}

\author{
Article history \\ Received July 13, 2017; accepted January 25, 2018. \\ Subject classification: \\ Terrestrial laser scanning; 3D modeling; Coastal erosion; Tuff cliff; Retreat analysis; Coroglio; Campi Flegrei; Italy.
}

\begin{abstract}
In this study, we present the results of an analysis of Terrestrial Laser Scanning (TLS) datasets, referred to multi-temporal (2013-2015) acquisition, aimed at evaluating volumetric changes and average retreat rates of the Coroglio tuff cliff, located in the western area of Naples (Italy) in the Campi Flegrei caldera. The multi-temporal analysis was carried out in two steps: firstly, we developed a preliminary $3 \mathrm{D}$ Cloudto-Cloud comparative analysis of point clouds obtained by TLS data processing, providing a view on geomorphological evolution; secondly, we obtained quantitative information by analyzing the differences between multi-temporal Digital Elevation Models. Finally, a morphometric analysis was carried out in order to evaluate both retreat and failure rates. Four types of landslides (rock fall, debris fall, earth flow, and soil slip) have been accurately mapped in the different sectors of the cliff. The morphological analysis shows that several morphological variations have been recognized in different areas of the cliff with a maximum retreat of $8 \mathrm{~m}$ at the foot of the cliff due to the erosive action of the sea on poorly lithified deposits. We estimated that the average linear retreat rate related to the Coroglio cliff between 2013-2015, was equal to $0.07 \mathrm{~m} / \mathrm{yr}$; the linear retreat rate is higher $(0.34 \mathrm{~m} / \mathrm{yr})$ at the base of the cliff, directly beaten by the sea waves. The results of the statistical analysis of the relationship between volume and area calculated for rock falls are consistent with the results of previous studies. Geo-structural analysis confirms that some discontinuity sets strongly control the failure kinematics.
\end{abstract}

\section{Introduction}

Sea cliff retreat is a discontinuous process in space and time that is dominated by areal erosion processes and mass movements, which are a relevant source of natural hazard [Redweik et al. 2009]. Hazard assessments require complete inventories of cliff failures, usu- ally based on multi-temporal aerial and terrestrial surveys using photogrammetric or Terrestrial Laser Scanning (TLS) methods [Carter et al. 2001, Slatton et al. 2007, Heritage and Large 2009]. The success of risk management associated coastal cliff erosion is also related to a robust quantification of cliff erosion rates [Earlie et al. 2013].

The quantification of retreat rates related to 1 and 10 year periods due to rapid erosion processes occurring along soft rock coastlines has been carried out by using airborne Light Detection and Ranging (LiDAR) technology [Young and Ashford 2006, Earlie et al. 2013, 2014].

In this study Terrestrial Laser Scanning (TLS) technology is used to estimate cliff volume changes and to determine linear retreat rates of sea-cliff in a specific type of soft rock, such as volcanic tuff.

The TLS is a remote sensing technique that is strongly developing in studies related to morphological evolution of the landscape due to landslides and erosion processes. In fact, the possibility of acquiring three-dimensional (3D) information of the ground with high accuracy and high spatial resolution has opened up new ways of investigating these phenomena and monitoring precursor signs of slope failures [Lague et al. 2013, Barbarella et al. 2013, Kromer et al. 2015]. Analysis of point cloud representations of topography have been used to study rock slope failures in different environments [Rosser et al. 2007, Sturzenegger et al. 2009, Stock et al. 2012, Royán et al. 2013].

The erosion process along soft-rock cliffs formed by pyroclastic rocks (e.g. unwelded tuff) are strongly influenced by weathering and sea actions and can be very 


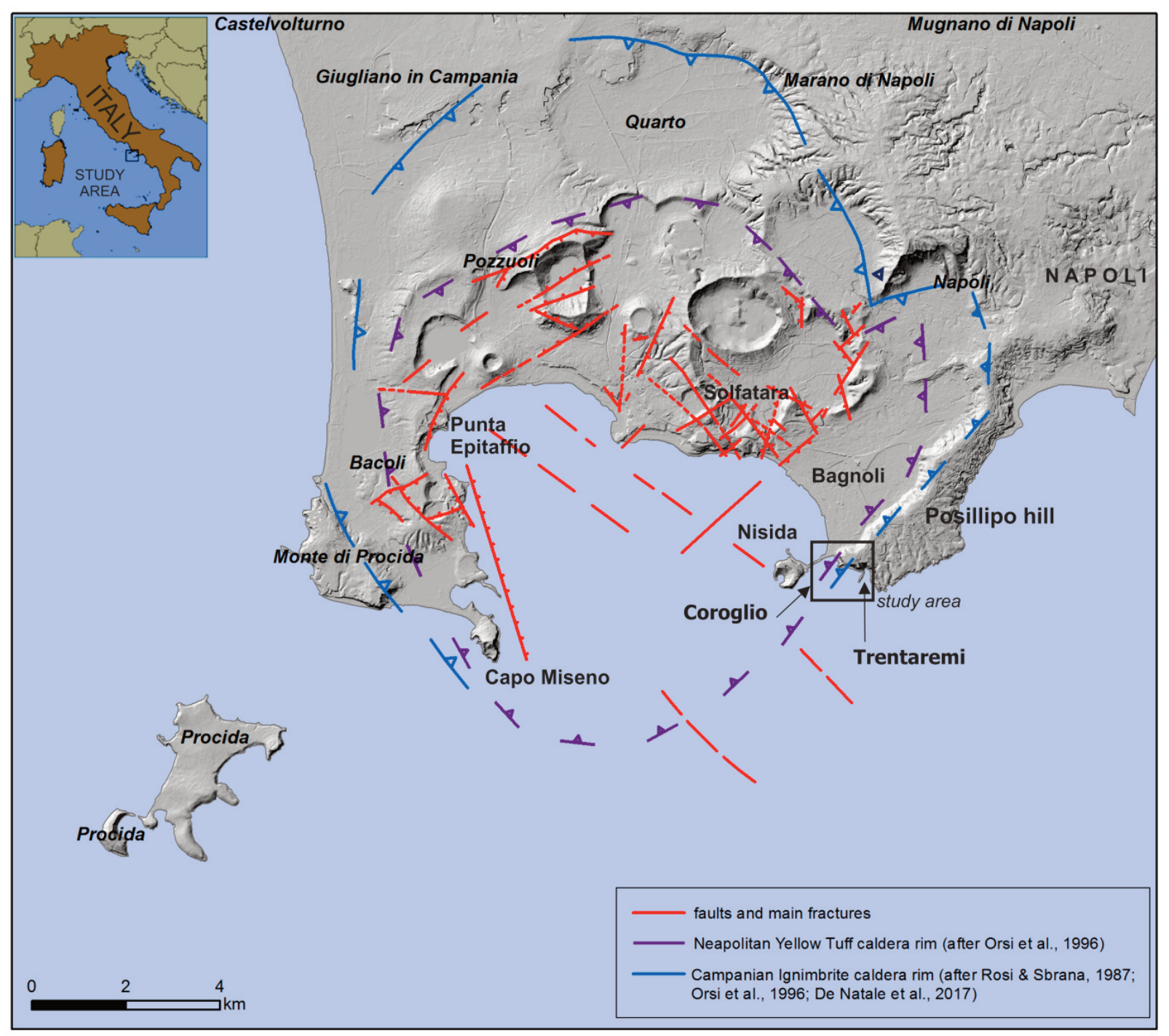

Figure 1. Structural sketch map of the Campi Flegrei caldera area with study area location.

intense [Yokota and Iwamatsu 1999, Ietto et al. 2015, Sacchi et al. 2015].

In this study, we present the results of an analysis of TLS datasets, referred to multi-temporal (2013-2015) acquisition, aimed at evaluating volumetric changes and average retreat rates of the Coroglio tuff cliff, located in the western area of Naples (Posillipo hill) (Figure 1). The Posillipo hill is a structural high located on the eastern rim of the Campi Flegrei caldera $(\mathrm{CFc})$, representing one of the areas with the highest volcanic risk in the world [De Natale et al. 2006].

The TLS multi-temporal surveys allowed us to observe significant morphological changes in different sectors of the cliff, related to different kinds of instability phenomena. Firstly, it was performed a comparison between 3D point clouds using the algorithm cloud-tocloud within CloudCompare software (CCs) [GirardeauMontaut 2015]. Then we used a GIS platform to represent and analyze the TLS datasets through $2.5 \mathrm{D}$ maps. By considering the geological context, it was created a frontal representation of the cliff (vertical mapping), where orthophoto, geology layer and DEM data were overlayered to identify and characterize landslide and erosion processes and quantify the volumes involved in last years.

\section{Geology and landslide processes at Coroglio cliff}

\subsection{Geological framework}

The volcanic history of the Campi Flegrei caldera area was dominated by two huge eruptions occurred about 39 and 15 ky ago [Rosi and Sbrana 1987, Orsi et al. 1996], followed by several medium to minor scale eruptions dating up to AD 1538, when the last eruption occurred in the area [Di Vito et al. 1987]. Vertical ground movements with rates from centimeters to meters per year characterize the dynamics of the area even during quiescent periods [Dvorak and Mastrolorenzo 1991, Di 


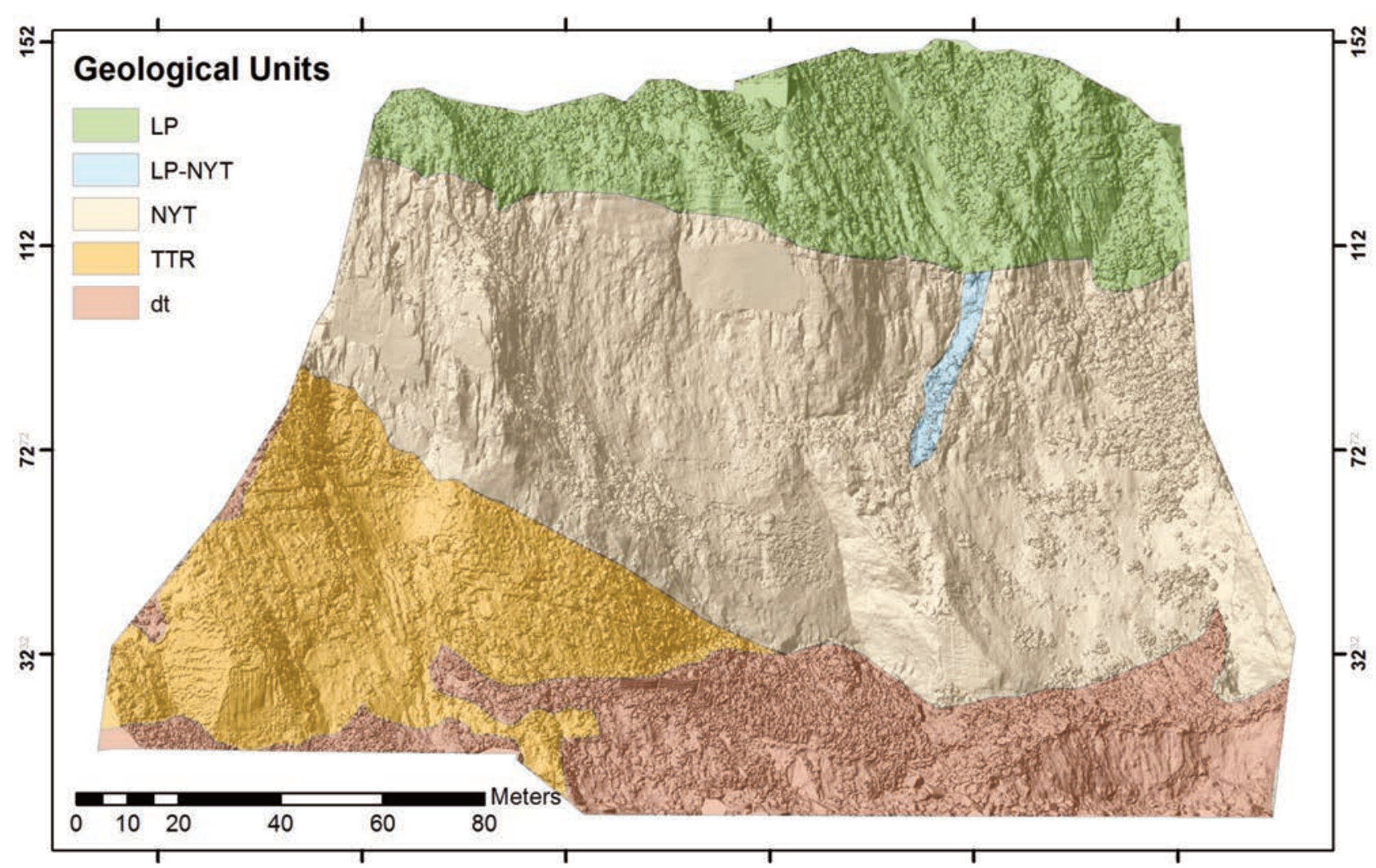

Figure 2. Geolitological vertical maps of Coroglio cliff (modified after Matano et al. 2016). Legend: LP, stiff to loose recent pyroclastic deposits and soils; LP-NYT, thin layer of LP deposits on NYT unit; NYT, Neapolitan Yellow Tuff; TTR, Trentaremi Tuff; dt, slope talus breccia and gravelly beach deposits.

Vito et al. 1999, Iuliano et al. 2015]. Since 1969, the area has been affected by several phases of ground uplift following several centuries of subsidence. The largest recent episodes of intense ground deformation are the two unrests occurred during the 1969-1972 and 1982-1984, causing a cumulative maximum uplift of over $3.5 \mathrm{~m}$, accompanied by intense seismicity. After a period of relative quiescence, a new unrest phase started in 2011 causing a maximum uplift of $350 \mathrm{~mm}$ to date, as recorded at the GPS station of RITE [Kilburn et al. 2017].

At the same time, the Campi Flegrei coastal zone results exposed to a series of natural and anthropogenic hazards, including earthquakes, landslides, flash floods and erosion [Beneduce et al. 1988, Esposito et al. 2015, Somma et al. 2015].

The Posillipo hill reaches an altitude of about 150 $\mathrm{m}$ a.s.l. and develops along a coastal segment of the urban area of Naples. The Posillipo structural high constitutes of the eastern boundary of the Bagnoli-Fuorigrotta depression and represents a segment of the structural border of the Campi Flegrei caldera [Orsi et al. 1996, De Natale et al. 2016], partially modified by erosive and dismantling processes [Russo et al. 1998]. It was formed during the large caldera collapse associated to the Neapolitan Yellow Tuff (NYT) eruptions [Deino et al. 2004, De Natale et al. 2016]. Prior to the NYT eruption the area was mostly emerged and it was characterized by the occurrence of older vents, namely the Trentaremi tuff cone, whose volcanic products has been overlain by the NYT deposits. The youngest volcanic activity in the area is represented by the eruption of Nisida tuff cone, dated 4 ka BP [Di Renzo et al. 2011, Scarpati et al. 2013].

\subsection{Stratigraphic units}

The stratigraphical sequence of pyroclastic deposits forming the Posillipo hill is well exposed along the Coroglio cliff (Figure 2). The analyzed sector of Coroglio cliff is about $150 \mathrm{~m}$ high and $250 \mathrm{~m}$ wide and it is directly beaten by the sea at its base.

The upper part of the cliff has slope angles varying from $35^{\circ}$ to $45^{\circ}$; it is represented by about $30 \mathrm{~m}$ of stiff, or partly loose, Holocene pyroclastic deposits and very loose reworked volcanoclastic deposits at the top (Loose Pyroclastic, LP unit). The intermediate sector of the cliff displays nearly vertical slopes and is formed by two tuff units, separated by an angular unconformity. The upper unit is formed by the Neapolitan Yellow Tuff (NYT formation), represented by alternating coarse-grained matrix-supported breccia, thin-laminated lapilli beds and 
waved welded fine ash deposits. The NYT face displays a relatively homogeneous texture with several sub-planar surfaces controlled by structural discontinuities (Figure 2). According to Froldi [2000], the NYT rock can be regarded as weak to moderately weak, according to the British Standards Institution [1981] classification. Locally thin layers of loose deposits of the LP unit covers the tuff (LP-NYT unit in Figure 2).

The lower unit is represented by the whitish yellow deposits of Trentaremi Tuff (TTR), which consist of slightly welded pumiceous coarse-grained fragments embedded in a sandy ash matrix and lapilli beds. The TTR face is characterized by diffused dm-scale vesicles and vacuoles due to differential erosion, markedly controlled by the bedding of pyroclastic deposits. The NYT unit, instead, is characterized by a complex system of mostly steep and planar structural discontinuities and fractures showing highly variable spacing, well-developed NE-SW and NW-SE directions, and subordinate N-S and E-W trends.

The base of the cliff is covered by slope talus breccia and gravelly beach deposits (dt unit) that mainly occur along the shoreline.

\subsection{Instability processes}

The tuff forming the cliff is highly erodible by sea waves and wind actions. In the last decades several block failures occurred along the cliffs due to fracturing and weathering of tuffaceous lithotype. After a major rock fall that occurred in 1990 [Froldi 2000], the northern sector of the upper part of the tuff cliff was been subject to reinforcement works realized by steel bars anchored and bolted to the consolidated layer and a wire mesh and steel cable network applied to the tuff wall. Laser scanning and geostructural studies have been performed on the Coroglio cliff in order to analyze the susceptibility to tuff failures [Matano et al. 2015, Somma et al. 2015, Matano et al. 2016]. Matano et al. [2015] identified six main discontinuty sets (F1 to F6) on Coroglio tuff cliff. They are characterized by vertical to oblique orientations both parallel and orthogonal to the cliff.

A geomorphological analysis allowed us to recognize several types of landslide processes [Varnes 1978, Cruden and Varnes 1996] acting on the different sectors of Coroglio cliff. Debris fall failures mainly affect the basal sector of the cliff, near the coastline, where slope debris and beach deposits ( $\mathrm{dt}$ unit) crop out. These coarse deposits are little lithified or loose, and are characterized by a widespread erosion mainly due to the action of the sea waves. Earth flows can be triggered in the upper part of the cliff, where there is a thick layer of loose pyroclastic deposits (LP unit). Rockfall affect the rocky sectors of the slope and primarily involves the tuff units (NYT and TTR) where there are several evidence of recent small failures. Lastly, soil slips may primarily affect the most superficial weathered layer of the TTR unit.

\section{Materials and Methods}

The methodology adopted in this study can be described in terms of a stepwise procedure, as illustrated in the flow chart of Figure 3. The multi-temporal analysis was carried out in two steps: firstly, we developed a preliminary 3D Cloud-to-Cloud comparative analysis of point clouds obtained by TLS data processing, providing a view on geomorphological evolution; secondly, we obtained quantitative information by analyzing the differences between multi-temporal DEMs. Finally, a morphometric analysis was carried out in order to evaluate both retreat rates and failure indices.

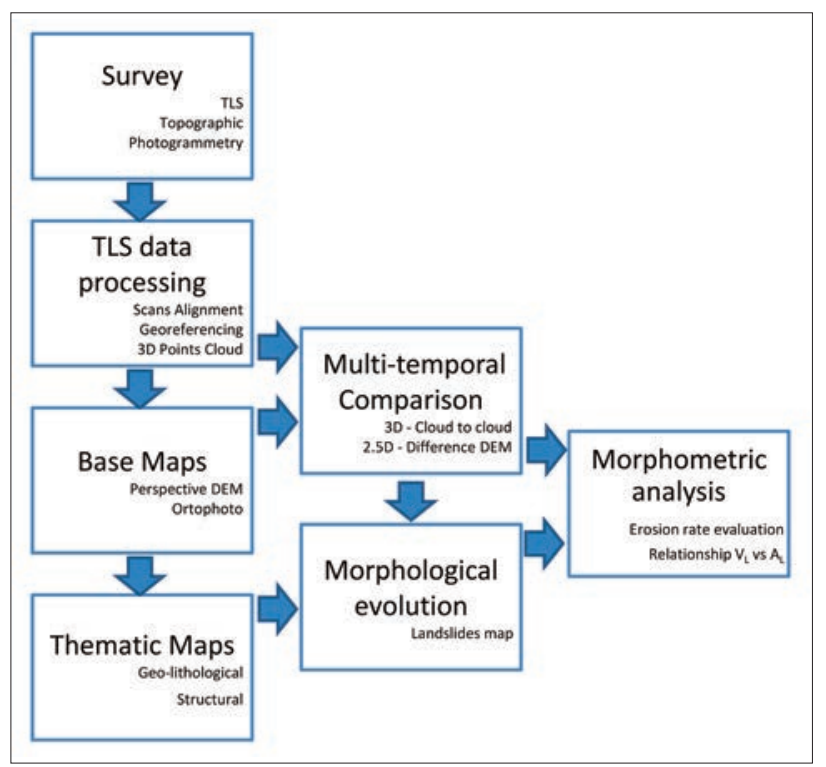

Figure 3. Workflow of the adopted methodology.

\subsection{Terrestrial Laser Scanning data survey}

In the recent years, the Terrestrial Laser Scanning (TLS) technique has been used for the purposes of environmental monitoring [Lague 2013] through the creation of high resolution Digital Surface Models (DSMs) and Digital Terrain Models (DTMs).

The TLS method allows the surveys of whole target areas and their $3 \mathrm{D}$ reproduction through a dense cloud of points. Each point contains information about $\mathrm{x}, \mathrm{y}, \mathrm{z}$ coordinates of the surface hit by the footprint, its amplitude, reflectance and pulse shape deviation.

The point cloud raw data were interpolated by using a triangulation algorithm for obtaining a derived 3D surface. Then a GIS processing allowed to obtain a transformation in a $2.5 \mathrm{D}$ raster [Rosser et al. 2005]. 
In our study we used a long-range laser scanner model RIEGL VZ1000 ${ }^{\circledR}$ with an integrated GPS receiver L1 antenna type. The instrument is equipped with a 12-megapixel external digital camera mounted on top of it. The pulsed emitted by TLS is near infrared (about $1550 \mathrm{~nm}$ ) with a pulse repetition rate ranging from 70 to $300 \mathrm{kHz}$, and a rate of acquisition spanning between 29,000 to 122,000 point/ second respectively; moreover, it can achieve the maximum distance of $1400 \mathrm{~m}$ at 70 $\mathrm{kHz}$ (http:/ / www.riegl.com/) [Caputo et al. 2014]. This instrument is based on Time of Flight (TOF) distance measurements which estimate the two-way travel time of the laser pulse reflection [Abellàn et al. 2014]. The scans have been performed from different points of view in order to prevent shaded areas and ensure a good cov-

\begin{tabular}{lcc}
\hline Survey & Date & Elapsed days \\
\hline$\# 1$ & 29 April 2013 & 0 \\
$\# 2$ & 10 June 2014 & 407 \\
$\# 3$ & 13 February 2015 & 655 \\
$\# 4$ & 4 March 2015 & 674 \\
\hline
\end{tabular}

Table 1. TLS surveys list.

erage of the area to investigate.

In addition to TLS survey, we have also performed a detailed topographic survey, framed in the UTMWGS84 system, by using a Leica TS12 total station, anchored to three cornerstones placed near the tuff cliff base. The topographic survey included also some of the control points fixed to the tuff cliff at different heights during the reinforcement works carried out in the 90's. In this way it was possible to georeference all the Terrestrial Laser scans into the UTM-WGS84 reference system.

Through the physically materialized cornerstone we easily put in the same position, orientation and coordinate system the different time lapse surveys.

The main output of the acquisition phase is a $3 \mathrm{D}$ point cloud and associated RGB images. Raw data files were then processed using RiScanPro $\mathbb{R}$ [RIEGL 2016]

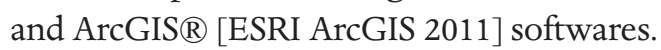

We performed four data acquisition surveys during 2013-2015 (Table 1).

The results of the first TLS survey have been used for geostructural analysis of the cliff [Matano et al. 2015, Somma et al. 2015]. The fourth survey was performed only one month after the third one due to the occurrence of a landslide which took place at the beginning of
March 2015. In each TLS survey two scans were carried out from different viewpoints (scan positions) with simultaneous acquisition of pictures from camera in order to texturize the dense point cloud with RGB image.

\subsection{Terrestrial Laser Scanning data processing}

The output of TLS data acquisition after pre-processing by using RiSCAN PRO® software [REIGL 2016] is represented by a $3 \mathrm{D}$ point cloud. During the pre-processing the point clouds obtained by each scan were aligned and georeferenced using the ICP algorithm (Iterative Closest Point) [Besl and McKay 1992] and then exported in LAS format.

The used Terrestrial Laser Scanner allows to discriminate among the different echoes turning back along the same direction (multi-target 3D), by classifying the echoes in "single", "first", "other" and "last" targets. The laser pulse may have multiple reflections especially when the laser beam hit vegetation, fences, trees, wires or more generally sharp edges. The multi-target 3D scan allows to filter recorded echoes, so allowing to discard the useless ones, corresponding to vegetation (i.e. blades or vegetation cover), in order to quickly obtain a "cleaned" point cloud. This is very useful to obtain a Digital Terrain Model (DTM) with the aim to monitor cliff evolution with multi-temporal survey.

Any filtering applied to the point cloud can result in a partly corrupted representation of the scanned surface. Filtering could also interfere with the generation of the Triangulated Irregular Network (TIN) in a geographic information system (GIS). Consequently, this could affect the accurate comparison of multi-temporal DEM raster for monitoring areas covered by vegetation which is mostly made of blades of grass and small bushes. For this reason, we did not applied filters for vegetation cleaning of the point cloud.

In order to compare multi-temporal scans, all data acquired over time need to be aligned. The alignment procedure was done following two steps. The first step, called coarse registration, consisted in a manual pre-alignment that allowed to identify at least four pairs of homologous points (topographic targets for total station fixed to the cliff, fractures, edges, boulders) in common between two georeferenced scans having more than $30 \%$ of overlap between each other. The distribution of the used control points (topographic targets) has some limitations due to their position, as they are a very limited sector of the cliff (Figure 4). So we obtained standard deviation $\sigma$ of $0.0295 \mathrm{~m}$, with an error increase moving away from the targets but always lower than $1 \mathrm{~cm}$.

The second step was needed to minimize the errors; it was used a plug-in Multi-Station Adjustment 


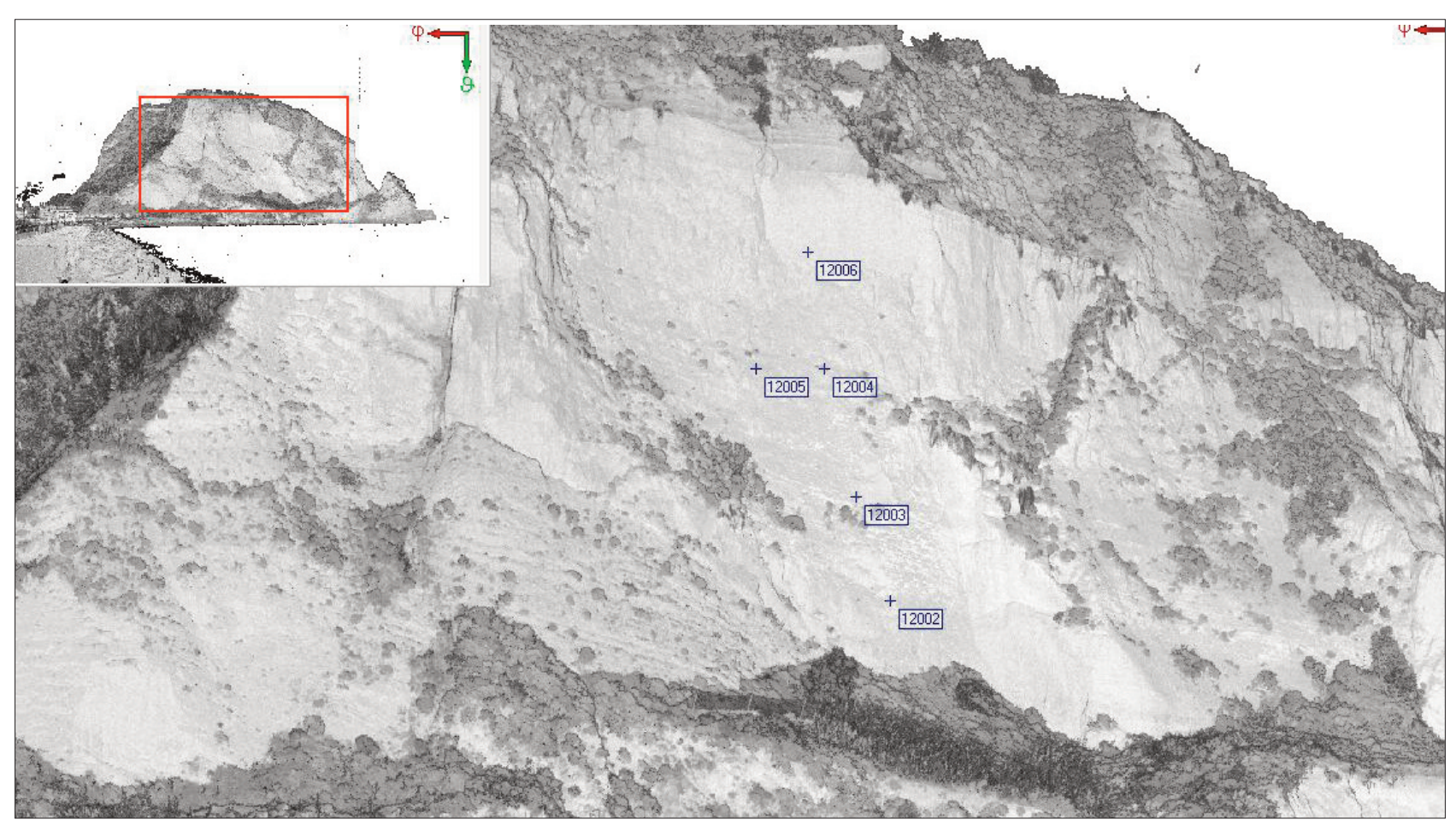

Figure 4. 2D view of reflectivity values of the point cloud with the location on the cliff of the topographic targets, or control points (cross), used for "coarse registration" and for topographic georeference.

(MSA) by RiScanPro $\AA$, based on an iterative closest point (ICP) algorithm. ICP allows the alignment of the scans using the normal vector of the estimate plane patches compared to the normal vector of a given reference plane. In this way we obtained further improvement in the standard deviation $\sigma(0.008 \mathrm{~m})$.

After the alignment process, it was possible properly evaluating the cliff retreat in some sector of the cliff.

\subsection{Analysis of change detection in TLS data}

In order to analyze morphological changes on the Coroglio cliff surface two different approaches were used and combined. The first one is based on distance calculation between two 3D point clouds acquired on different dates using Multiscale Model to Model Cloud Comparison (M3C2) algorithm with CloudCompare open source software (http://www.cloudcompare.org/), while the second one is a GIS-based 2,5D processing approach which relies on a rasterization/gridding process of the clouds. The M3C2 algorithm allows evaluating the differences between two point clouds expressed as the distance between points of different clouds in a 3D space, in order to define and identify volumetric and morphological changes [Lague et al. 2013]. In order to reduce time-consuming calculations, the point clouds have been decimated before M3C2 processing [GirardeauMontaut et al. 2015]. The resampling has been set with a minimum space between points of $0.05 \mathrm{~m}$. To compute $\mathrm{M} 3 \mathrm{C} 2$ algorithm the point cloud was then sub- sampled at $0.1 \mathrm{~m}$ representing the "core" point value. This is the value around which a vector normal is defined using a plane fitting the neighbor points [Brodu and Lague 2012, Lague et al. 2013]. The M3C2 algorithm takes into account the roughness of the surface and the error due to the alignment of the clouds. It also allows defining the scale of analysis that is a function of the density of the sub-sampled cloud [Lague et al. 2013].

This approach was used to individuate the main morphological changes on the $3 \mathrm{D}$ point clouds in order to estimate the annual changes of the cliff surface (20132014 and 2014-2015) and the total variation, comparing the first measurement carried out in 2013 and the last in 2015. In order to map the limits of the main morphological changes occurred during 2013-2015 and to calculate the volumetric changes that occurred in recent years with a very high degree of accuracy, a 2.5D raster (vertical DEM) was produced adopting the most suitable vertical projection plane by taking into account the general morphological conditions and the spatial orientation of the cliff.

The point cloud data have been processed with ArcGis $\AA$ software with the aim to represent them by means of DEMs, moving from a $3 \mathrm{D}$ model to a $2.5 \mathrm{D}$ model of the cliff where numerous information were stored as $\mathrm{h}(\mathrm{x}, \mathrm{y})$ matrix. This achievement has been possible through the creation of Triangulated Irregular Network (TIN) models. The TIN model was suitably referred to a local coordinate system, parallel to 
the cliff main orientation that was obtained by a rotation of the axes.

In order to both minimize the loss of information and to have a good level of detail on the model, it was chosen the same size of the sampling of the point cloud $(0.05 \mathrm{~m})$ as the average spacing for the creation of the TIN. From the TIN layer, a Digital Elevation Model (DEM) raster with a cell size $0.05 \mathrm{~m}$ was generated with a specific tool of ArcGis $\AA$.

Once the vertical DEMs were obtained, some further GIS processings were performed to map and quantitatively define volumetric changes occurred along the cliff. The arithmetic operator MINUS implemented in $\operatorname{ArcGis} \AA$ allows to make the difference between two DEM rasters by simply subtracting on a cell-by-cell basis the DEM values. The result is a new raster (i.e. MINUS raster) that shows the differences between the two rasters, allowing us to identify different areas with positive or negative values. The obtained MINUS raster exhaustively shows the topographic changes, as areas with positive values mean accumulation of deposits, while areas with negative values show a retreat of the cliff. The latter could be due to, a loss of vegetative cover due to an erosion process or thin landslides, or to a loss of rock mass due to rockfalls. A similar approach, based on DEM of differences, has been used [Wheaton et al. 2010] to estimate net changes in morphological sediment budgets.

The MINUS raster allows only to quantify the changes point by point, expressed in differences of horizontal distance to the reference plane measured in meters; it is not possible to evaluate the volumes of eroded/accumulated materials.

The volumetric differences between DEM rasters can be calculated by using the CUTFILL tool in Ar$c G i s \AA$. If we had indiscriminately applied this tool to the whole cliff surface we would have included in our computation the volumetric variations due to the vegetation growth or decline, as well as soils and rocky materials. The changes of the seasonal vegetation can be very consistent in large sectors of the cliff, mainly at the top and at the base of the cliff and along scattered small ledges along the tuff strata. For this reason, we had carefully mapped the cliff sectors with uncovered tuffs, soil/debris deposits or with only sparse grass cover using orthophoto, and we applied our change detection analysis only to these sectors. Moreover, by considering the average seasonal growth of grass cover and the errors in TLS data processing and acquisition, we have defined a $0.20 \mathrm{~m}$ threshold value, as horizontal topographic change threshold, below which the morphology is assumed to have undergone no significant change.
The evaluation of eroded/accumulated volumes for quantifying cliff retreat rates has been carried out considering only filtered sectors of the cliff by producing a mask of the other sectors (covered by greenery or characterized by value under the defined threshold) of the cliff. This task was performed by applying the CUTFILL tool in ArcGIS after a careful check by discarding in the MINUS raster the areas where the addition or loss of material was not caused by erosion or landslide processes. This is a method to quantify the gained or lost volumes of rocky/soil materials involved in the morphological changes of the tuff cliff.

\subsection{Photogrammetric processing}

We applied the Structure from Motion (SfM) technique of photogrammetry to obtain a vertical orthophoto which can be used as cartographic reference layer in the GIS software. The SfM technique allows to generate $3 \mathrm{D}$ models from a sequences of images taken from different positions and with a high overlap.

A number of 10 pictures were taken with a digital camera (mod. Canon 5D mark II, resolution 21 Megapixel, $50 \mathrm{~mm}$ lens) at about $400 \mathrm{~m}$ of distance from the base of the cliff.

The images were then processed with Agisoft $\mathbb{R}$ Photoscan Software [Agisoft 2014]. After the topographic targets located on the cliff had been recognized in the images, the same coordinates of the control points used to georeference the TLS data were associated to them in order to obtain a perfect alignment. Finally, a dense point cloud and a mesh were extracted, allowing creating an orthophoto with geometric resolution of 6 $\mathrm{cm}$ referred to a selected projection plane.

\section{Results of analysis of change detection on TLS data}

The TLS data analysis reveals that several evidences of morphological variations of considerable extent occurred between 2013-2015 in different sectors of the cliff. The analysis allows also to quantify the volumes involved and the rates of the instability phenomena occurred during the TLS surveys.

The results of the difference between 2013 and 2015 point clouds, obtained by using M3C2 algorithm with no filtering of vegetation cover, is shown in Figure 5. Negative values mean that the points of the 2015 cloud are more far away from scan position than points of the 2013 cloud, while positive values mean the opposite. Blue colors show negative values due to a loss of material (vegetation cover, soil, or tuff) from the cliff, whereas red colors are positive values due to accumulation processes of tuff blocks and/or landslide deposits or 


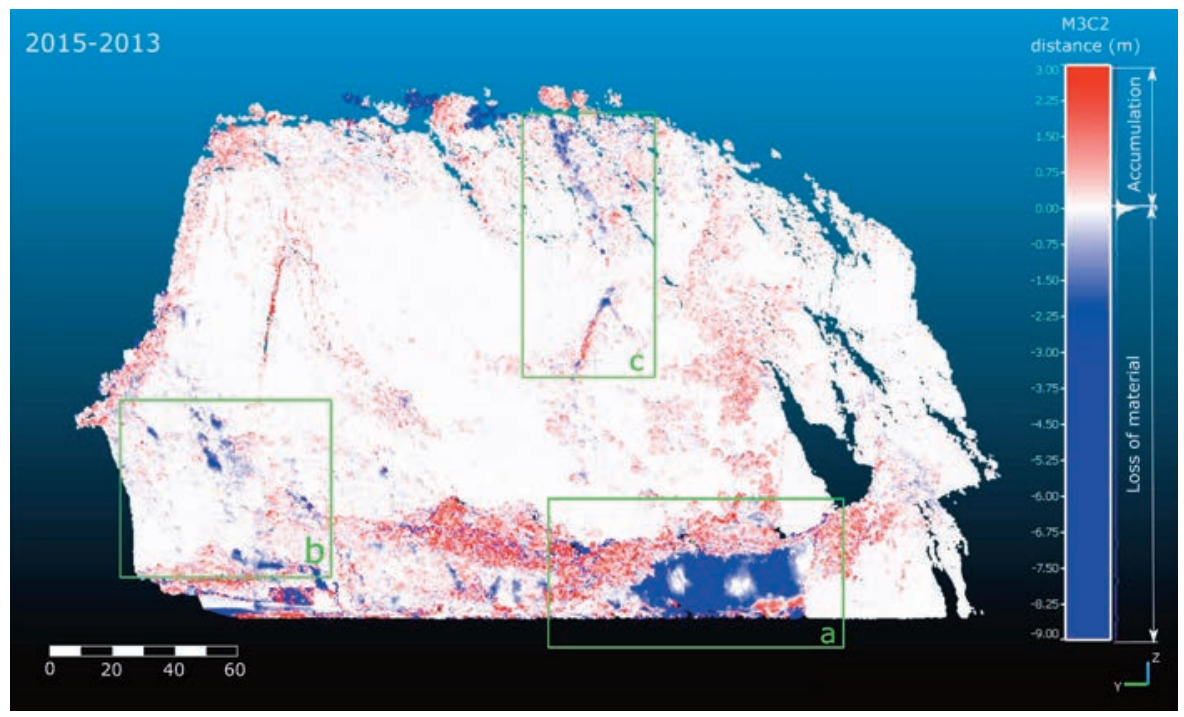

Figure 5. Estimated differences between point clouds related to TLS survey in 2013 and 2015 obtained with M3C2 algorithm in CCs. The sectors characterized by major changes are framed with green boxes. The dotted line in box "a" shows the profile location of Figure. 8.

to vegetation growth. Three sectors are characterized by negative changes helpful to evaluate cliff retreat, while scattered positive values are mainly referred to vegetation growth (Figure 5).

The TLS data were treated in GIS with a rasterization/gridding process of the point clouds. The difference between DEM rasters, filtered by vegetation, allowed to calculate erosion and retreat rates.
In Figure 6 the layer of distance differences (expressed in meters), obtained applying the MINUS tool between the 2015 and 2013 DEMs after vegetation filtering, is overlapped to a vertical orthophoto related to a 2015 survey. Three sectors with relevant morphological variations caused by instability phenomena on the cliff have been identified (Figure 6); they correspond to the same sectors identified by the M3C2 analysis (Figure

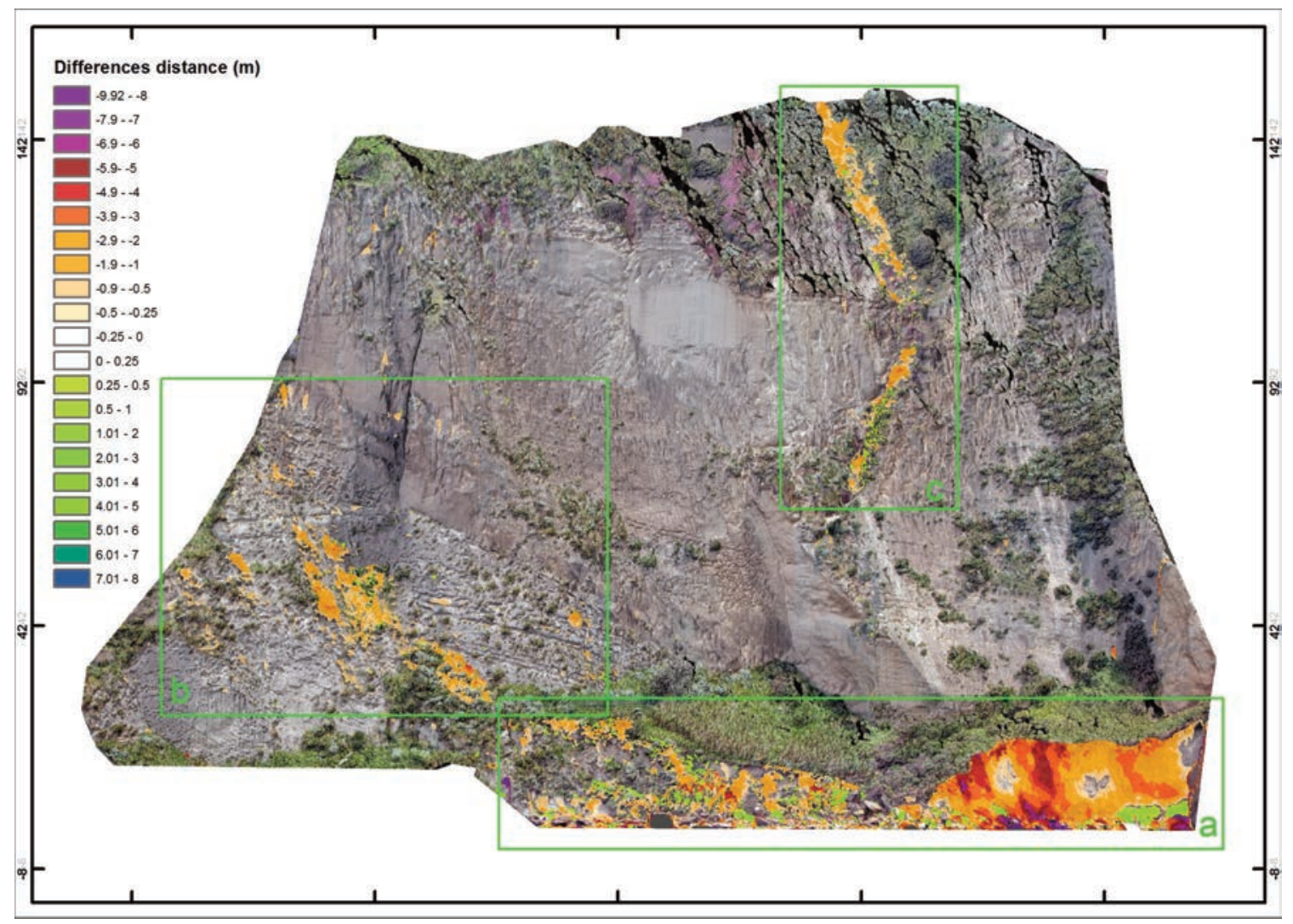

Figure 6. Difference between vertical DEMs derived by 2015-2013 surveys. The sectors characterized by major changes are framed with green boxes. Values in the $-0.25 /+0.25 \mathrm{~m}$ interval are not considered (null color). The orthophoto is dated 2015 . 


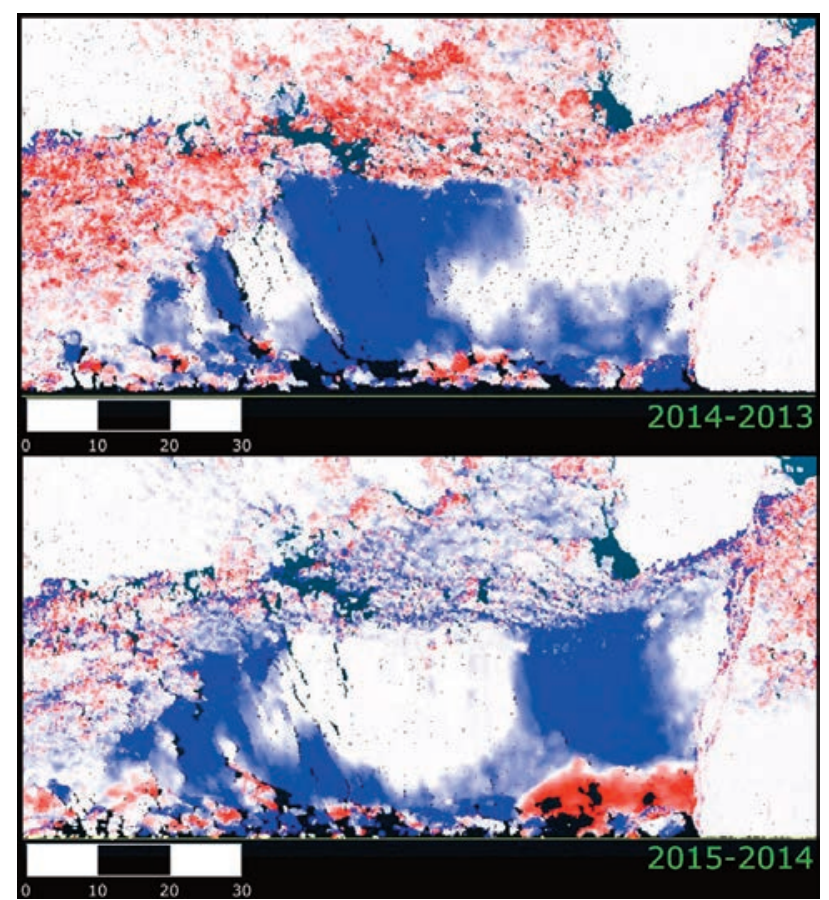

Figure 7. Evolution of the basal sector of the cliff (Figure 5, box a) for 2014-2013 (top), 2015-2014 (down) obtained with M3C2 algorithm in CCs. For 2015-2013 overall changes see Figure 5.

5) and are characterized by different outcropping lithologies and types of landslide and erosion processes.

In Figures 5 and 6 (box a) it is evident that the tuff cliff is characterized by the strongest localized erosion with a retreat up to $9 \mathrm{~m}$ in two years. The evolution of this basal sector of the cliff, as derived by M3C2 analysis, is shown in Figure 7 for 2014-2013 and 2015-2014. In particular, in the period 2014-2013, a central failure (blue color) occurred, bounded by two substantially stable lateral areas (white color). A relevant failure occurred between 2014-2015 in the lateral sectors, as testified also by the accumulation of landslide material (red color) at the cliff base. The profile variations for 2013, 2014 and 2015 years (Figure 8) show the retreat measured along a cross-section at the foot of the cliff. In 2014 a basal retreat, probably due to sea wave erosive action, can be seen; in 2015 it is followed by a strong backward failure in the above contiguous sector coupled with a related accumulation area at its base. These processes affected loose, coarse debris and deposits (Figure 2) and are probably due to the erosive action of the sea waves during storms. Differences between DEMs related to basal sector of the cliff (Figure 9) show the same evolution in central and lateral sectors. During the 2014-2013 interval (Figure 7, top), there is no relevant accumulation of deposits whilst these occurred in 2015-2014 (Figure 9, green colors). In the other two sectors (sectors b and c in Figures 5,6 ) different instability phenomena and geological factors have been identified. In sector b (Figure 10) two main mechanisms have been identified: tuff block failures, although of modest size, and soil slips (or slides) affecting mainly the

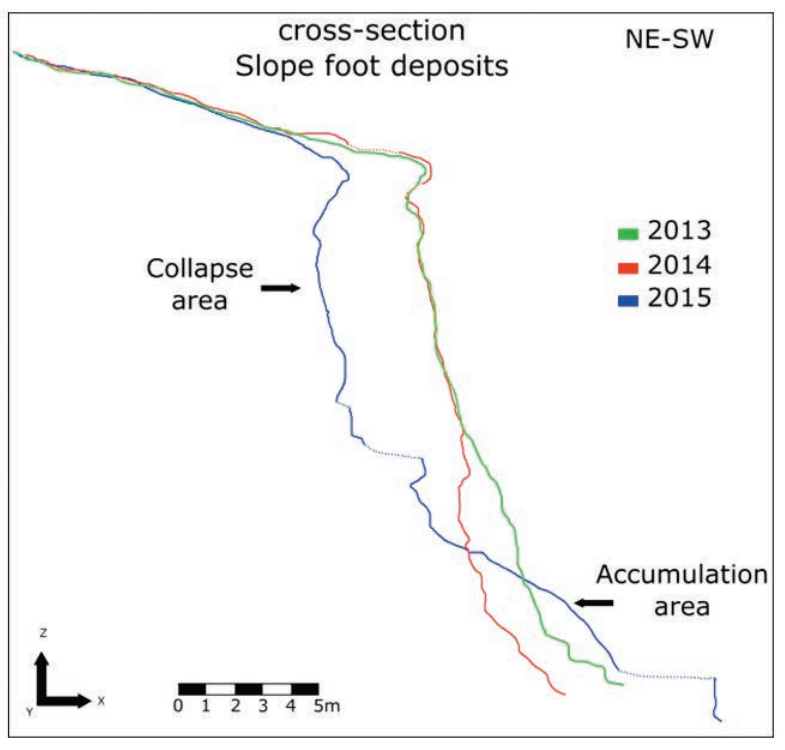

Figure 8. Cross-section at cliff basal sector (for profile location see Figure 5). Dashed lines are interpolated data in occluded areas.

thin, weathered part of tuff and its grass cover. The formation involved is Trentaremi Tuff (TTR unit). This formation is also characterized by a widespread erosion as testified by the presence of small cavities which give rise to a typical erosive shape, locally named "tafoni" [Ietto et al. 2015]. Only small differences can be observed between the two time intervals (Figure 10). Finally, in zone c (Figures $5,6)$ very poor erosive processes are present (Figure 11). A relevant landslide occurred between the 13th February and the 4th March 2015; the scar is located in the loose Holocene pyroclastic deposits of the uppermost part of the cliff and involved also the thin vegetation cover; the landslide mass flowed along the intermediate sector of the cliff covering the tuff (Figure 11).

\section{Analysis of landslide and erosion processes}

The analysis of the morphological changes occurred during 2013-2015 has been correlated to the lithological characteristics of geological units cropping out the Coroglio cliff. Four types of landslides (rock fall, debris fall, earth flow, and soil slip) have been accurately mapped in the different sectors of the cliff (Figure 12).

In detail, rockfalls affect the rocky sectors of the cliff, involving the fractured tuffs of the NYT and TTR units where there are some evidences of recent little scarps where fresh, unweathered tuff crops out. Debris falls occur mainly near the shoreline at the base of the cliff, where slope debris and coarse beach deposits ( $\mathrm{dt}$ unit) crop out. These deposits are slightly lithified or loose, so they are characterized by a widespread erosion due to the action of the sea waves. Soil slips affect the most superficial, thin, weathered layer of the TTR unit and its grassy cover. A main earthflow event oc- 

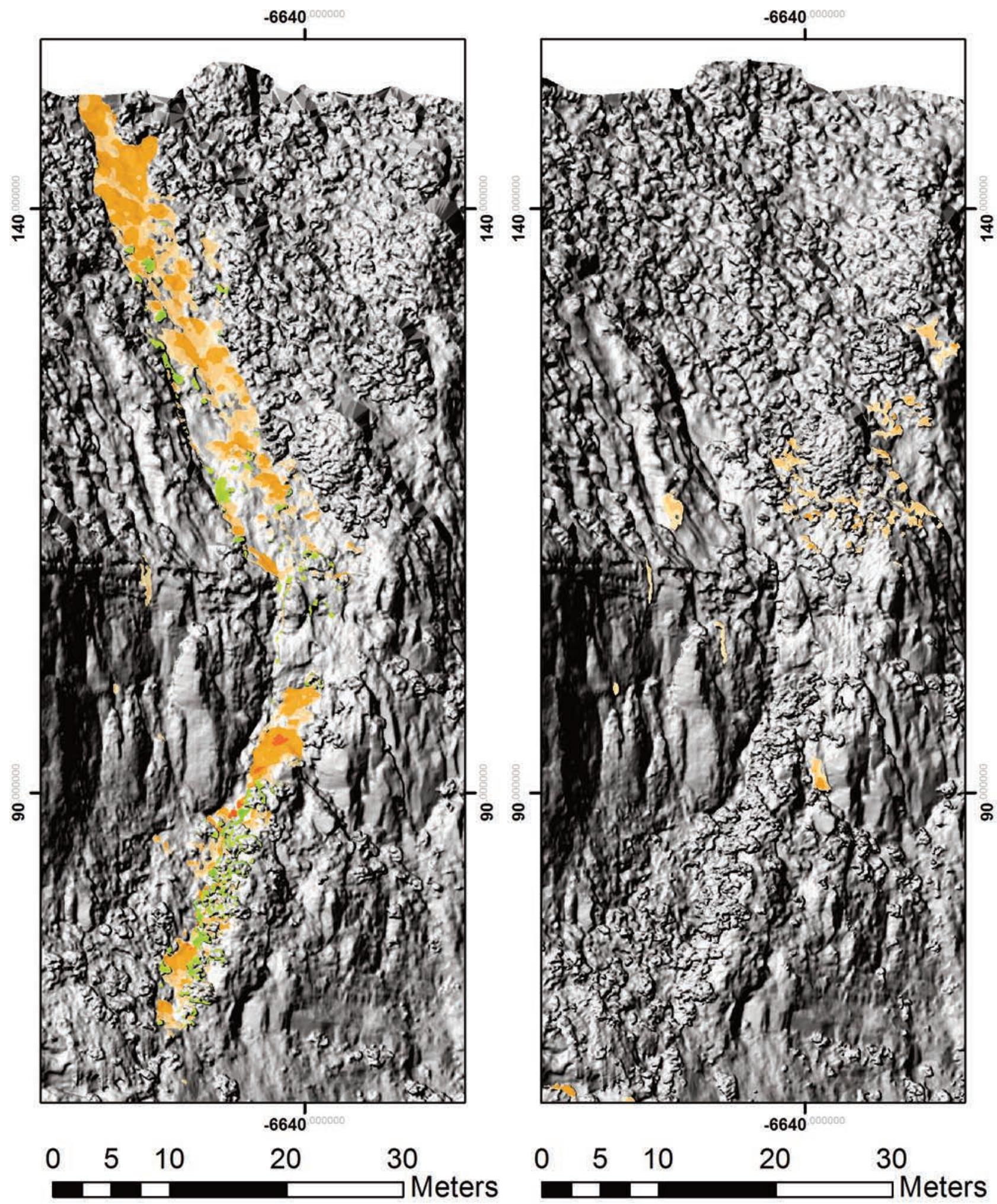

Figure 11. Evolution of the upper part of the southern sector of the cliff (Figure 6, box c), characterized by stiff to loose Holocene and recent pyroclastic deposits (LP unit) and Neapolitan Yellow Tuff (NYT unit) outcrops, for 2015-2014 (left) and 2014-2013 (right), based on difference between DEMs. For 2015-2013 overall changes and legend see Figure 6.

curred at the end of February 2015 from the upper layer of the cliff formed by loose pyroclastic deposits (LP unit) and flowed along the intermediate sector of the tuff cliff where its deposits are locally layered on NYT small edges.

\subsection{Volume calculation of failures}

The quantitative analysis of topographic changes has allowed to quantify mapped areas and estimated volumes that have been deposited (Table 2) and lost 


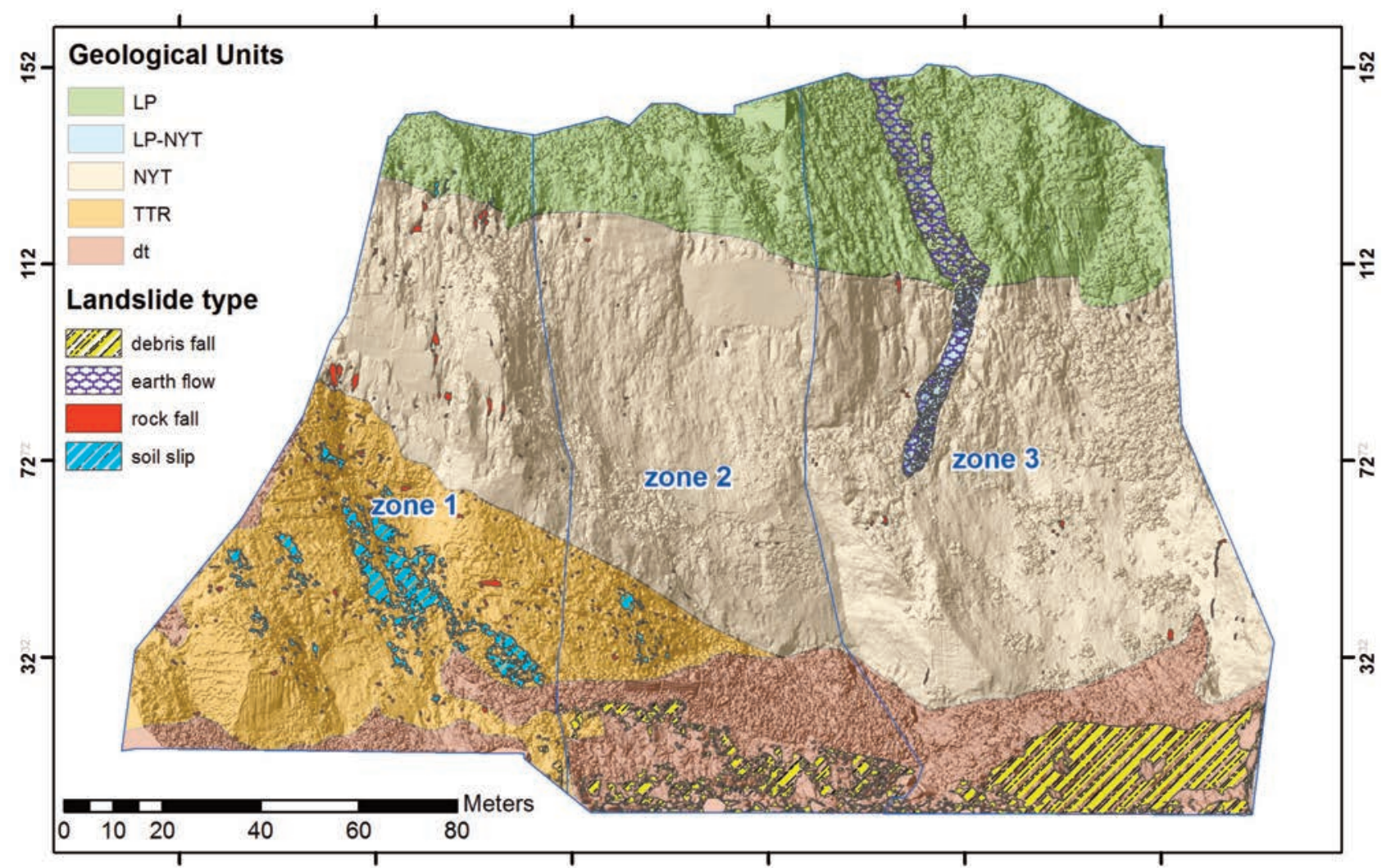

Figure 12. Geological units and landslide types occurred on Coroglio cliff in 2015-2013 interval.

(Tables 3, 5) by means of landslide processes with reference to lithological units (Table 3), different types of failures (Table 4) and morphological zones of the cliff (Table 5, and see Figure 12).

On the whole investigated cliff surface (total area of $26904 \mathrm{~m}^{2}$ ), in the time period between the 29th April 2013 and 4th march 2015 (674 days, about 1.85 years), we obtained an estimated volume of about $3.500 \mathrm{~m}^{3}$ (Table 3 ) of eroded material (rock and soil) and $210 \mathrm{~m}^{3}$ (Table 2) of deposited material (soil, debris and blocks).

The deposited material has an average thickness of about $70 \mathrm{~cm}$ (Table 2, column $\mathrm{V} / \mathrm{A}$ ), even if it needs to be considered that some of the deposited materials had directly fallen in the seawater, therefore they are not included in this calculation. About the $7 \%$ of the cliff is marked as landslide area, even if the values are very different in the various units, ranging from $60 \%$ for LP-NYT and $26 \%$ for dt to $0.2 \%$ for

\begin{tabular}{lccc}
\hline & $\begin{array}{c}\text { Vertical } \\
\text { projected area } \\
(\mathbf{A})\end{array}$ & $\begin{array}{c}\text { Estimated } \\
\text { deposited } \\
\text { volume }(\mathbf{V})\end{array}$ & V/A \\
\hline $\mathrm{m}^{2}$ & $\mathrm{~m}^{3}$ & $\mathrm{~m}^{3} / \mathrm{m}^{2}$ \\
$\begin{array}{l}\text { landslide depo- } \\
\text { sits }\end{array}$ & 304.37 & -210.22 & -0.69 \\
\hline
\end{tabular}

Table 2. Landslide deposits: estimated area and volume.
NYT (Table 3, column $A_{L} / A_{G} U$ ). An average depth of failure surface can be estimated for the different units; it ranges from $2.41 \mathrm{~m}$ for $\mathrm{dt}$ to $0.66 \mathrm{~m}$ for NYT, while the mean value is $1.81 \mathrm{~m}$ (Table 3 , column $\mathrm{V} / \mathrm{A}_{\mathrm{L}}$ ). In agreement with Young and Ashford [2006] we considered the total volume eroded from the cliff (the cliff surface area and the time span) and estimated in $0.07 \mathrm{~m} / \mathrm{yr}$ the average linear retreat rate related to the Coroglio cliff during 2013-2015 years. The linear retreat rate is higher $(0.34 \mathrm{~m} / \mathrm{yr})$ considering only the basal sector of the cliff, directly beaten by the sea waves.

Additionally, if we consider the different landslide types, we have different percentage values of area currently affected by landslides respect to the whole area potentially affected by the considered type of landslide. The values range from $24 \%$ for debris falls to $1 \%$ for rockfalls (Table 4 , column $A_{L} / A_{G U}$ ). The average depth of failure surface can be estimated for the different types of failures; it ranges from $2.41 \mathrm{~m}$ for debris fall to $1.07 \mathrm{~m}$ for soil slips, $0.79 \mathrm{~m}$ for rockfalls and $0.65 \mathrm{~m}$ for earthflows (Table 4 , column $\mathrm{V} / \mathrm{A}_{\mathrm{L}}$ ).

With reference to the three morphological sectors recognized in the cliff we have obtained different rates (Table 5). Zone 1 (western sector) is characterized by $5 \%$ of the area affected by landslides with an average depth of $1.08 \mathrm{~m}$, zone 2 (central sector) is characterized by $5 \%$ of the area affected by landslides with an 
CAPUTO ET AL.

\begin{tabular}{|c|c|c|c|c|c|c|}
\hline Unit & $\begin{array}{l}\text { Landslide area } \\
\left(\mathrm{A}_{\mathrm{L}}\right)\end{array}$ & $\begin{array}{l}\text { Eroded volume } \\
\text { (V) }\end{array}$ & $A_{G U}$ & $\mathrm{~A}_{\mathrm{L}} / \mathrm{A}_{\mathrm{GU}}$ & $\mathrm{V} / \mathrm{A}_{\mathrm{GU}}$ & $\mathrm{V} / \mathrm{A}_{\mathrm{L}}$ \\
\hline & $\mathrm{m}^{2}$ & $\mathrm{~m}^{3}$ & $\mathrm{~m}^{2}$ & & $\mathrm{~m}^{3} / \mathrm{m}^{2}$ & $\mathrm{~m}^{3} / \mathrm{m}^{2}$ \\
\hline $\mathrm{dt}$ & 1167.12 & 2809.24 & 4506.6 & 0.26 & 0.623 & 2.41 \\
\hline LP & 230.61 & 151.45 & 4709.8 & 0.05 & 0.032 & 0.66 \\
\hline LP-NYT & 105.56 & 67.17 & 177.37 & 0.60 & 0.379 & 0.64 \\
\hline NYT & 52.27 & 45.03 & 12773.58 & 0.00 & 0.004 & 0.86 \\
\hline TTR & 370.4 & 405.37 & 4736.92 & 0.08 & 0.086 & 1.09 \\
\hline TOTAL & 1925.96 & 3478.26 & 26904.27 & 0.07 & 0.129 & 1.81 \\
\hline
\end{tabular}

Table 3. Landslide data with reference to lithologic units. Acronyms: geological unit area $\left(\mathrm{A}_{\mathrm{GU}}\right)$.

\begin{tabular}{|c|c|c|c|c|c|c|}
\hline Landslide type & $\begin{array}{l}\text { Landslide area } \\
\left(A_{L}\right)\end{array}$ & $\begin{array}{l}\text { Eroded volume } \\
\text { (V) }\end{array}$ & $A_{\mathrm{GU}}$ & $A_{L} / A_{G U}$ & $\mathrm{~V} / \mathrm{A}_{\mathrm{GU}}$ & $\mathrm{V} / \mathrm{A}_{\mathrm{L}}$ \\
\hline & $\mathrm{m}^{2}$ & $\mathrm{~m}^{3}$ & $\mathrm{~m}^{2}$ & & $\mathrm{~m}^{3} / \mathrm{m}^{2}$ & $\mathrm{~m}^{3} / \mathrm{m}^{2}$ \\
\hline soil slip & 318.23 & 341.37 & 3781.4 & 0.08 & 0.090 & 1.07 \\
\hline earth flow & 331.83 & 216.11 & 3474.23 & 0.10 & 0.062 & 0.65 \\
\hline rock fall & 94.84 & 74.58 & 14668.348 & 0.01 & 0.005 & 0.79 \\
\hline debris fall & 1181.06 & 2846.21 & 4980.292 & 0.24 & 0.571 & 2.41 \\
\hline TOTAL & 1925.96 & 3478.27 & 26904.27 & 0.07 & 0.129 & 1.81 \\
\hline
\end{tabular}

Table 4. Landslide erosion data for the different landslide types. Acronyms: geological unit area $\left(\mathrm{A}_{\mathrm{GU}}\right)$; for each landslide type we have considered only the area of the sectors of the geological units affected by the considered landslide type.

\begin{tabular}{|c|c|c|c|c|c|c|}
\hline $\begin{array}{l}\text { Zone } \\
\text { (geological units) }\end{array}$ & $\begin{array}{l}\text { Landslide area } \\
\qquad\left(A_{L}\right)\end{array}$ & $\begin{array}{l}\text { Eroded volume } \\
\text { (V) }\end{array}$ & $A_{z}$ & $A_{L} / A_{Z}$ & $\mathrm{~V} / \mathrm{A}_{\mathrm{Z}}$ & $\mathrm{V} / \mathrm{A}_{\mathrm{L}}$ \\
\hline & $\mathrm{m}^{2}$ & $\mathrm{~m}^{3}$ & $\mathrm{~m}^{2}$ & & $\mathrm{~m}^{3} / \mathrm{m}^{2}$ & $\mathrm{~m}^{3} / \mathrm{m}^{2}$ \\
\hline \multicolumn{7}{|l|}{ Zone 1} \\
\hline (LP, NYT, TTR, dt) & 377.67 & 406.68 & 7441.68 & 0.05 & 0.055 & 1.08 \\
\hline \multicolumn{7}{|l|}{ Zone 2} \\
\hline (LP, NYT, TTR, dt) & 377.67 & 505.61 & 8076.72 & 0.05 & 0.063 & 1.34 \\
\hline \multicolumn{7}{|l|}{ Zone 3} \\
\hline (LP, LP-NYT, NYT, dt) & 1170.63 & 2565.97 & 11385.85 & 0.10 & 0.225 & 2.19 \\
\hline TOTAL & 1925.97 & 3478.26 & 26904.25 & 0.07 & 0.129 & 1.81 \\
\hline
\end{tabular}

Table 5. Landslide erosion data for the different morphological zones of the cliff. Acronyms: zone area (AZ)

average depth of $1.34 \mathrm{~m}$ and zone 3 (eastern sector) is characterized by $10 \%$ of the area affected by land- 


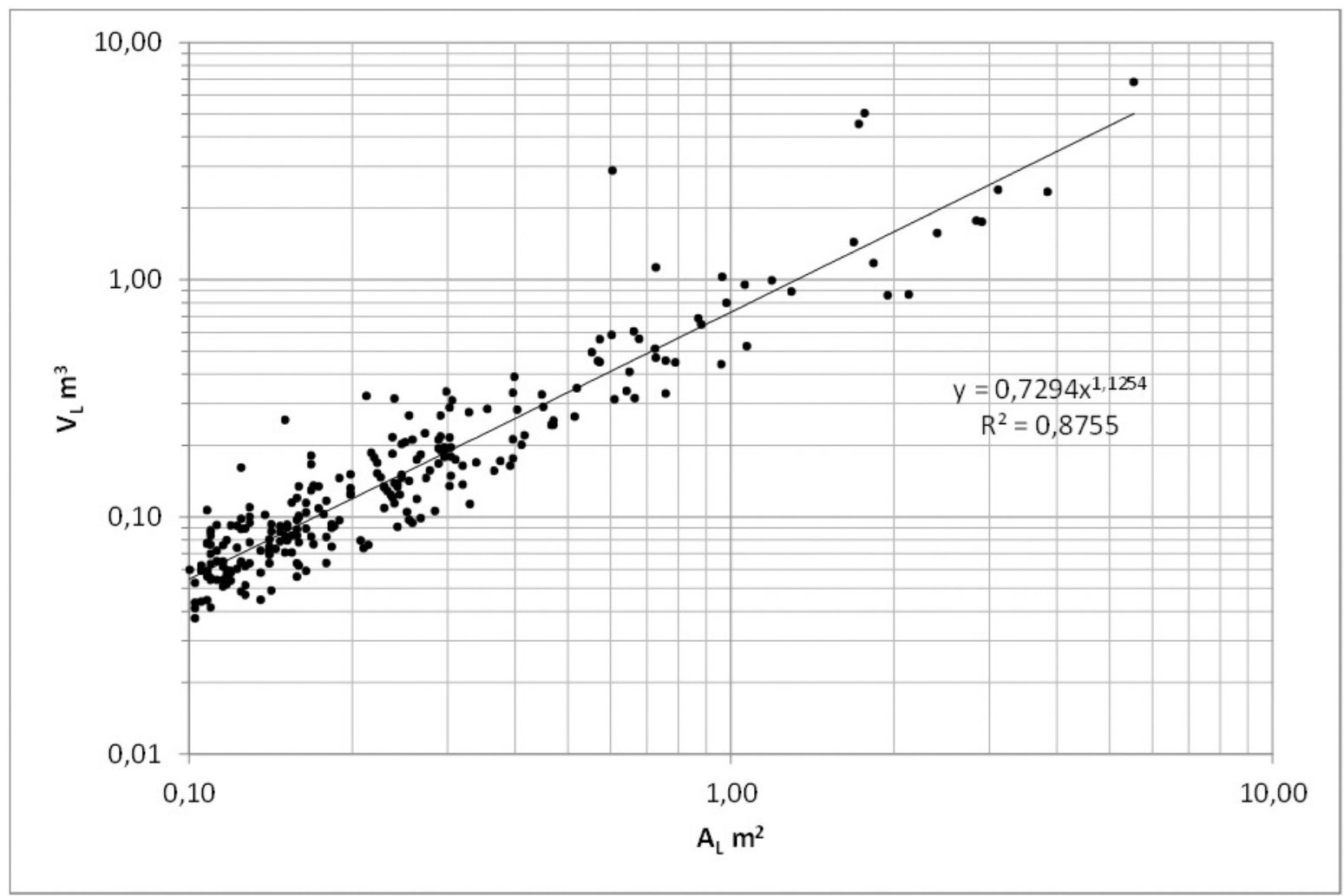

Figure 13. Log-log diagram of empirical relationship between landslide area $A_{L}$ and $V_{L}$ for rockfalls identified on Coroglio cliff

slides with an average depth of $2.19 \mathrm{~m}$.

\subsection{Relationship between $V_{L}$ and $A_{L}$}

Several studies have addressed the relationship between area and volume of landslides for the susceptibility and hazard analysis [Guzzetti et al. 2009].

In our study, an empirical relationship between area $\left(A_{L}\right.$, expressed in $\left.m^{2}\right)$ and volume $\left(V_{L}\right.$, expressed in $\mathrm{m}^{3}$ ) of landslide has been determined with reference to rockfalls.

Following Guzzetti et al. [2009] the Equation (1) was applied for fitting the empirical data.

$$
\mathrm{V}_{\mathrm{L}}=\varepsilon \times \mathrm{A}_{\mathrm{L}}^{\alpha}
$$

The relationship takes the form of a power law in a log-log diagram with a scaling exponent $\alpha=1.12$ (Figure 13). The range of empirical values $(\mathrm{N}=245)$ of $V_{L}$ is $10^{-1} \mathrm{~m}^{3}<V_{L}<10 \mathrm{~m}^{3}$, while the range of $A_{L}$ is 10 ${ }^{2} \mathrm{~m}^{2}<\mathrm{A}_{\mathrm{L}}<10 \mathrm{~m}^{2}$. The robust linear fitting (87.5\%) shows a good correlation coefficient $\mathrm{R}^{2}$, furthermore the error associated to standard error of the scaling exponent $\alpha$ is low. A good correlation between $A_{L}$ and $\mathrm{V}_{\mathrm{L}}$ has been identified also for very low magnitude events, confirming a geometrical relationship.

This finding is relevant to the determination of rock fall susceptibility at Coroglio cliff.

\subsection{Relationship between frequency and magnitude of rockfall}

The quantitative assessment of the hazard depends on the possibility of identifying the relations between landslide magnitude and frequency, which may be expressed by landslide frequency-magnitude (M/f) curves.

In order to estimate the probability of slope failures as a function of magnitude of rockfall, we constructed the frequency-magnitude (M/f) curves by correlating the relative frequency of occurrence (referred to a period of 2 years) with the cumulate volume or cumulate area of recognized rockfall failures, considered as good estimations of the magnitude. The frequency distribution of events in a given magnitude class follows power laws above a magnitude threshold, and a characteristic "rollover" effect may occur below this threshold, usually due to an unrealistic underestimation of smaller events [Corominas et al. 2014].

In our study, two frequency-magnitude curves were obtained by considering as magnitude both area or estimated volume of landslides (Figure 14). The two curves display a similar linear trend in a bi-logarithmic plot with a flattening for low-magnitude landslides with $\mathrm{M}<20 \mathrm{~m}^{2}$ or $\mathrm{M}<30 \mathrm{~m}^{3}$ (rollover effect). The steep part of the curves is well defined by a power law relation with a slope of - 2.602 for volume curve and - 3.175 


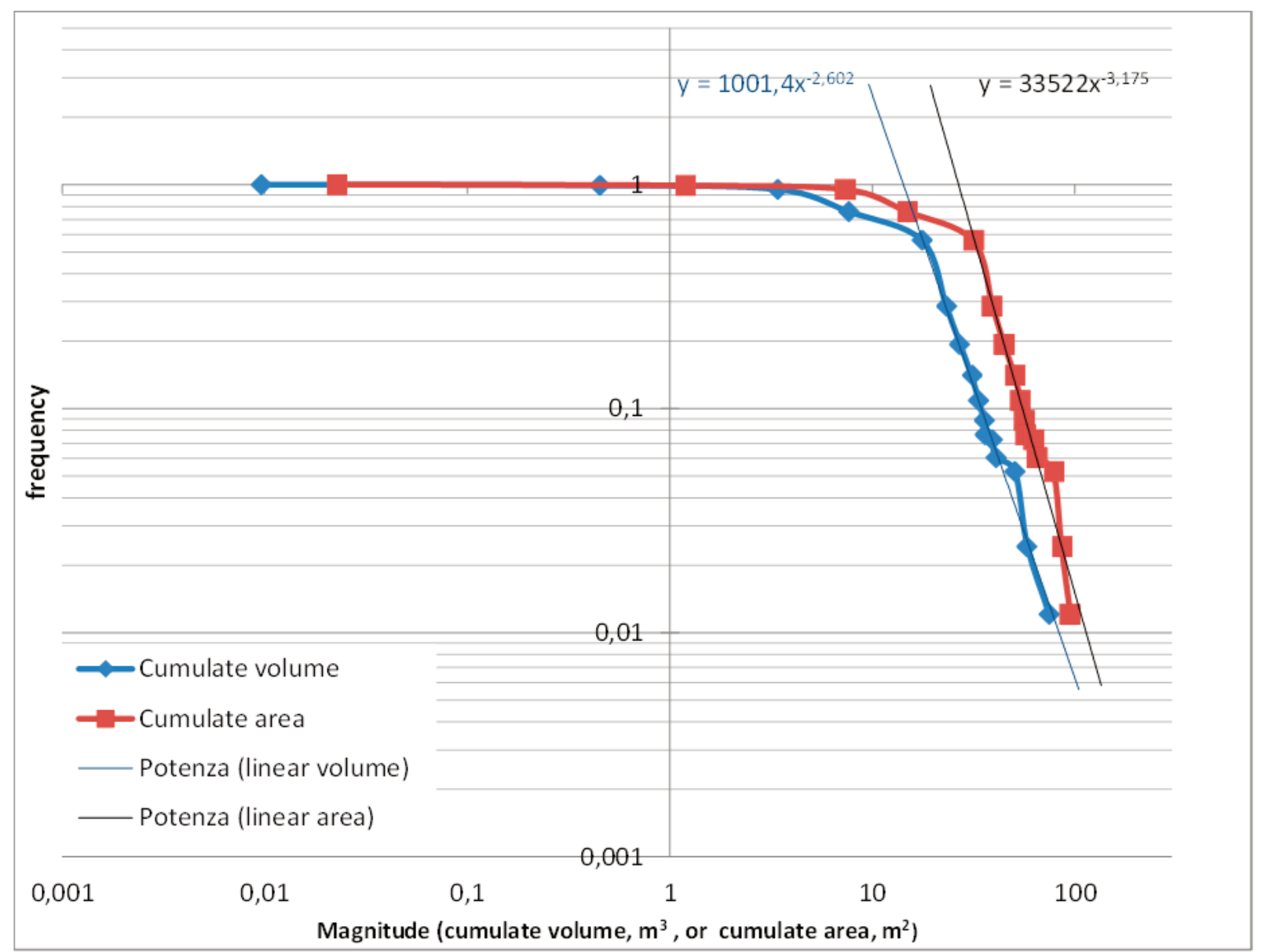

Figure 14. M/f diagram for rockfalls recognized at Coroglio between 2013 and 2015.

for area curve. The power law component is an expected result and shows a tendency to an increase in the number of unstable sectors of the cliff for less frequent failures (within the 2 years of observation). A rollover effect (i.e. the data are no longer represented by the power law) is observed in all curves for $\mathrm{f}>0.5$, as usual for $\mathrm{M} / \mathrm{f}$ curves [Corominas and Moya 2008].

The rollover effect is normally not observed in complete inventories, and it can be a consequence of a number of factors including:

1) censoring completeness and/or under-sampling for the smallest failures [Hungr et al. 1999, Stark and Hovius 2001, Malamud et al. 2004];

2) physical and geomorphological properties of the slope controlling the formation and initiation of landslides [Guzzetti et al. 2002, 2008, Brunetti et al. 2009, Guthrie and Evans 2004, Malamud et al. 2004].

In our analysis, as we do not inventory the failures with area lower than $0.1 \mathrm{~m}^{2}$, the rollover effect cannot be due to limitations of the data processing but to physical and geomorphological properties of the slope.

\subsection{Analysis of structural control on failures}

Geo-structural analysis of discontinuity sets in a rock mass is the main factor used in the assessment of failure susceptibility. It allows to identify susceptible areas towards different types of collapse on the basis of the failure mechanisms analysis. Matano et al. [2015] identified six main discontinuity sets (F1 to F6) on Coroglio tuff cliff based on a geo-structural analysis.

Discontinuity sets F1 to F4 are vertical to sub-verti$\mathrm{cal}$ (dip values from $65^{\circ}$ to $90^{\circ}$ ), while F5 and F6 sets are inclined to sub-horizontal (dip values from $0^{\circ}$ to $65^{\circ}$ ) [Matano et al. 2015]. Set F1 is sub-parallel to the cliff and shows a significant erosional control. Sets F2, F3 and F4 have a well-defined structural control but different relationships with cliff aspect. Set F2 is sub-parallel to oblique to the cliff, set F3 set is oblique to sub-orthogonal to the cliff and the F4 is mainly sub-orthogonal to the cliff [Matano et al. 2015]. The F1 to F4 sets often identify tuff blocks isolated from the bedrock side. Sets F5 and F6 mainly display a stratigraphic control. They are often sub-orthogonal to the cliff and occasionally cut the isolated tuff blocks at their base.

In order to detect the structural conditions that have 


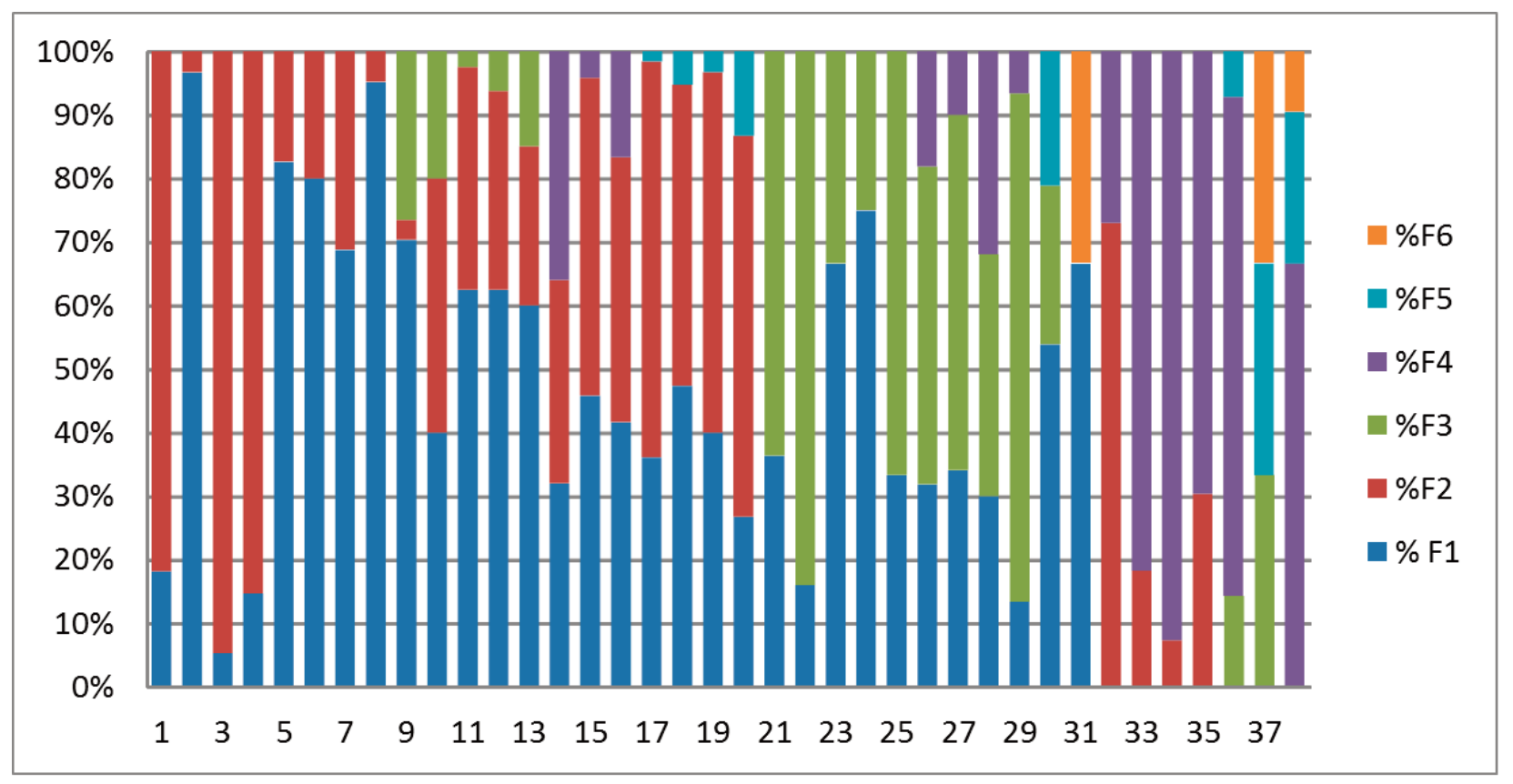

Figure 15. Joint set distribution for selected failures.

\begin{tabular}{cc}
\hline Joint sets & \% \\
\hline F1 & 90 \\
F2 & 75 \\
F3 & 69 \\
F4 & 59 \\
F5 & 65 \\
F6 & 25 \\
\hline
\end{tabular}

Table 6. Joint sets occurrence in detachment area of rockfalls

influenced the occurred failures along the cliff, a statistical analysis has been performed on discontinuity sets bordering the 420 rockfall polygons recognized on the cliff (Figure 13$)$. About $55 \%$ of rockfall is bordered by all joint sets; the remaining $45 \%$ is bordered by a variable number (from 1 to 5 ) of joint sets (Table 6); the more present set is the F1.

If we consider the presence of at least two sets we have the distribution of occurrence shown in Table 7 , where the most frequent couples of sets are F1-F2 (70\%), F1-F3 (63\%), F1-F5 (59\%) and F2-F5 (53\%).

By considering only failures controlled by 2 or 3 joint sets, we can observe the distribution of Figure 15 . The F5 and F6 sets seem less involved in block instability. In brief, we can assume that structural control strongly prevails on stratigraphic control on tuff block failures.

\section{Discussion and conclusions}

The use of innovative TLS methodologies in the

\begin{tabular}{cc}
\hline Joint sets & \% \\
\hline F1-F2 & 70 \\
F1-F3 & 63 \\
F1-F4 & 51 \\
F1-F5 & 59 \\
F1-F6 & 21 \\
F2-F3 & 52 \\
F2-F4 & 46 \\
F2-F5 & 53 \\
F2-F6 & 16 \\
F3-F4 & 45 \\
F3-F5 & 51 \\
F3-F6 & 16 \\
F4-F5 & 43 \\
F4-F6 & 11 \\
F5-F6 & 18 \\
\hline
\end{tabular}

Table 7. Occurrence of coupled joint sets in detachment area of rockfalls.

analysis of failures and cliff erosional retreat has proved to be very valuable, particularly in the context of the Campi Flegrei caldera, characterized by a complex geological stratigraphy inherited by a multistage eruptive history.

The main objective of this study is the definition of the geomorphological evolution of the Coroglio tuff cliff and its quantitative analysis during a multitemporal monitoring (years 2013 - 2015). The Coroglio cliff is characterized by several deposits of 
volcanic origin and is representative of a typical coastal morphology of volcanic areas.

The integration of geological and geomorphological data with a high detailed DEM, obtained by applying the TLS methodology, has allowed to accurately define the stratigraphic limit between the different geological formations, characterize the several fracture sets and recognize the detachment areas of failures and erosive process. The processing procedure obtained by adopting the MSA algorithm for alignment of 3D point clouds obtained by scans carried out during different TLS surveys, allowed to elaborate a DEM with a standard deviation of $0.008 \mathrm{~m}$. In the following processing steps, point clouds have been decimated to $0.05 \mathrm{~m}$ for the hardware and software processing limits (CCs and ArcGis). Finally, a further $0.20 \mathrm{~m}$ threshold has been applied in the analysis of the temporal differences between the obtained DEMs in order to better highlight the geomorphologic variations of the forehead, since it has been seen that lower values are only related to seasonal grow variations of vegetation.

The obtained 3D point clouds allowed the recognition and identification of different types of landslides during multi-temporal comparison. Four types of landslide mechanisms were recognized: soil slip, earth flow, rock fall and debris fall. For each type, the GIS processing has allowed a quantitative analysis on involved areas and rock/soil volumes. In particular, the results of the morphological analysis show that several morphological variations have been recognized in different areas of the cliff, with a maximum retreat of $8 \mathrm{~m}$ at the foot of the cliff due to the erosive action of the sea on poorly lithified deposits $(\mathrm{dt})$.

These data represent the starting point for further statistical analyses useful to define quantitative morphological evolution, and space-time relationships needed to determine the hazards and the predictive evolution models. The results of the statistical analysis of the relationship between volume and area calculated for rock falls are consistent with the results of previous studies and confirm the good correlation between them, even in the case of magnitude very low $(<100)$. From the frequency-magnitude $(\mathrm{M} / \mathrm{f})$ curves for rockfall events obtained both for $V_{L}$ and $A_{L}$, the rollover effect is observed in all curves for $\mathrm{f}>0.5$ probably due to technical limitations of the data processing, as we do not inventory at all the failures with an area less than $0.2 \mathrm{~m}^{2}$.

Geo-structural analysis shows that discontinuity sets from F1 to F4 strongly control the failures kinematics. In conclusion, the results obtained from our analysis confirm that the TLS methodology is a valuable tool for analyzing with a high level of detail the morphological evolution of tuff cliff and for monitoring their susceptibility and hazard levels of failures.

Acknowledgements. The present work is supported and funded by the Italian Ministry of Education, University and Research (MIUR) under the project PON01_01525 "MONitoraggio Innovativo per le Coste e l'Ambiente marino"-"MONICA". We thank R. Di Maso of the Caldicott School for the review of the English language. Moreover, we thank the reviewers for the detailed comments and the constructive suggestions.

\section{References}

Abellán A, Oppikofer T, Jaboyedoff M, Rosser NJ, Lim M, Lato MJ (2014). Terrestrial laser scanning of rock slope instabilities. Earth surface processes and landforms, 39(1), 80-97.

Agisoft LLC (2014). Agisoft PhotoScan User Manual: Professional Edition.

Barbarella M, Fiani M (2013). Monitoring of large landslides by Terrestrial Laser Scanning techniques: field data collection and processing. European Journal of remote sensing, 46(1), 126-151.

Barbarella M, Fiani M, Lugli A (2015). Landslide monitoring using multitemporal terrestrial laser scanning for ground displacement analysis. Geomatics, Natural Hazards and Risk, 6(5-7), 398-418.

Beneduce P, D'Elia G, Guida M. (1988). Slope morphodynamics of the Phlegraean area (Campania): mass movements and linear erosion. Memorie Società Geologica Italiana, 41, 949-961.

Besl PJ, McKay ND (1992). Method for registration of 3 D shapes. In Robotics-DL tentative (pp. 586-606). International Society for Optics and Photonics.

British Standards Institution (1981). Code of practice for site investigations (BS 5930, 149 pp.). London: HMSO.

Brodu N, Lague D (2012). 3D terrestrial lidar data classification of complex natural scenes using a multiscale dimensionality criterion: applications in geomorphology. ISPRS J. of Photogramm. and Remote Sensing 2012, 68, 121-134, doi: $10.1016 /$ j.isprsjprs.2013.04.009.

Caputo T, Somma R, Marino E, Troise C, De Natale G (2014). Mounting calibration procedure to colorize point clouds of REIGL VZ-1000 using RiSCAN PRO® software. Rapporti Tecnici INGV 2014, 267, ISSN 2039-7941.

Carter W, Shrestha R, Tuell G, Bloomquist D, Sartori M (2001). Airborne laser swath mapping shines new light on Earth's topography. EOS, Transactions American Geophysical Union, 82(46), 549-555.

Cruden DM, Varnes DJ (1996). Landslide types and pro- 
cesses. In: Turner AK, Schuster RL (eds) Landslides investigation and mitigation. Transportation research board, US National Research Council. Special Report 247, Washington, DC, Chapter 3, pp. 36-75

De Natale G, Troise C, Pingue F, Mastrolorenzo G, Pappalardo L, Battaglia M, Boschi E (2006). The Campi Flegrei caldera: unrest mechanisms and hazards. Geological Society, London, Special Publications, 269(1), 25-45.

De Natale G., Troise C., Mark D., Mormone A., Piochi M., Di Vito M. A., Isaia R., Carlino S., Barra D., and Somma R (2016). The Campi Flegrei Deep Drilling Project (CFDDP): New insight on caldera structure, evolution and hazard implications for the Naples area (Southern Italy), Geochem. Geophys. Geosyst., 17, 4836-4847, doi:10.1002/2015GC006183.

Deino AL, Orsi G, de Vita S, Piochi M (2004). The age of the Neapolitan Yellow Tuff caldera-forming eruption (Campi Flegrei caldera-Italy) assessed by 40 Ar/39 Ar dating method. Journal of Volcanology and Geothermal Research, 133(1), 157-170.

Di Renzo V, Arienzo I, Civetta L, D'Antonio M, Tonarini S, Di Vito MA, Orsi G (2011). The magmatic feeding system of the Campi Flegrei caldera: architecture and temporal evolution. Chemical Geology, 281(3), 227-241.

Di Vito M, Lirer L, Mastrolorenzo G, Rolandi G (1987). The 1538 Monte Nuovo eruption (Campi Flegrei, Italy). Bulletin of Volcanology, 49(4), 608-615.

Di Vito MA, et al. (1999). "Volcanism and deformation since 12,000 years at the Campi Flegrei caldera (Italy)." Journal of Volcanology and Geothermal Research 91.2: 221-246.

Dvorak JJ, Mastrolorenzo G (1991). The mechanisms of recent vertical crustal movements in Campi Flegrei caldera, southern Italy. Geological Society of America Special Papers, 263, 1-47.

Earlie CS, Masselink G, Russell PA, Shail RK (2013). Sensitivity analysis of the methodology for quantifying cliff erosion using airborne LiDAR - examples from Cornwall, UK. In: Conley, D.C., Masselink, G., Russell, P.E. and O'Hare, T.J. (eds.), Proceedings 12th International Coastal Symposium (Plymouth, England), Journal of Coastal Research, Special Issue No. 65, pp. 470-475, ISSN 0749-0208.

Esposito G, Fortelli A, Grimaldi G M, Matano F, Sacchi M, (2015). I fenomeni di flash flood nell'area costiera di Pozzuoli (Napoli, Italia): risultati preliminari sull'analisi dell'evento del 6 novembre 2011 Rendiconti Online della Società Geologica Italiana, 34, 74-84.

ESRI ArcGIS Desktop "Release 10." Redlands, CA: Environmental Systems Research Institute (2011)
Froldi P (2000). Digital terrain model to assess geostructural features in near-vertical rock cliffs. Bulletin of Engineering Geology and the Environment, 59(3), 201-206.

Girardeau-Montaut, D. (2015). CloudCompare (version 2.7) [GPL software]. Retrieved from http:/ / www. cloudcompare. org.

Guzzetti F, Ardizzone F, Cardinali M, Rossi M, Valigi D. (2009). Landslide volumes and landslide mobilization rates in Umbria, central Italy. Earth and Planetary Science Letters, 279(3), 222-229.

Heritage G, Large A. (Eds.). (2009). Laser scanning for the environmental sciences. John Wiley \& Sons.

Ietto F, Perri F, Filomena L (2015). Weathering processes in volcanic tuff rocks of the "Rupe di Coroglio" (Naples, southern Italy): Erosion-rate estimation and weathering forms. Rend Online Soc Geol It 33:5356.

Iuliano S, Matano F, Caccavale M, Sacchi M (2015). Annual rates of ground deformation (1993-2010) at Campi Flegrei, Italy, revealed by Persistent Scatterer Pair (PSP)-SAR interferometry. International Journal of Remote Sensing, 36(24), 6160-6191.

Kilburn RJC, De Natale G., Carlino S., (2016). Progressive approach to eruption at Campi Flegrei caldera in southern Italy, Nature communications, doi:10.1038/ncomms15312

Kromer RA, Hutchinson DJ, Lato MJ, Gauthier D, Edwards T, (2015). Identifying rock slope failure precursors using LiDAR for transportation corridor hazard management. Engineering Geology, 195, 93103.

Lague D, Brodu N, Leroux J, (2013). Accurate 3D comparison of complex topography with terrestrial laser scanner: Application to the Rangitikei canyon (N-Z). ISPRS Journal of Photogrammetry and Remote Sensing 82 (2013) 10-26

Matano F, Iuliano S, Somma R, Marino E, Del Vecchio U, Esposito G, Molisso F, Scepi G, Grimaldi GM, Pignalosa A, Caputo T, Troise C, De Natale G, Sacchi M (2016). Geostructure of Coroglio tuff cliff, Naples (Italy) derived from terrestrial laser scanner data. Journal of Maps, published online 07 April 2015. doi: http: / / dx.doi. org/10.1080/17445647.2015.1028237.

Matano F, Pignalosa A, Marino E, Esposito G, Caccavale M, Caputo T, Sacchi M, Somma R, Troise C, De Natale G (2015). Laser Scanning Application for Geostructural analysis of Tuffaceous Coastal Cliffs: the case of Punta Epitaffio, Pozzuoli Bay, Italy European Journal of Remote Sensing - 2015, 48: 615637 doi: 10.5721 / EuJRS20154834

Orsi G, De Vita S, Di Vito M (1996). The restless, resur- 
gent Campi Flegrei nested caldera (Italy): constraints on its evolution and configuration. Journal of Volcanology and Geothermal Research, 74(3-4), 179214.

Redweik P, Matildes R, Marques F, Santos L, (2009). Photogrammetric methods for monitoring cliffs with low retreat rate. Journal of Coastal Research, SI 56 (Proceedings of the 10th International Coastal Symposium), 1577 - 1581. Lisbon, Portugal, ISSN 07490258.

RIEGL (2016). RiSCAN PRO software. http: / / www.riegl.com/uploads / tx_pxpriegldownloads/11_DataSheet_RiSCAN-PRO_2016-0919_01.pdf

Rosi M, Sbrana A (1987). Phlegraean Fields:(CNR Quaderni de "La Ricerca Scientifica” 9), 175 pp. Conz. Naz. Delle Ric., Rome, Italy.

Rosser N, Lim M, Petley D, Dunning S, Allison R (2007) Patterns of precursory rockfall prior to slope failure. J. Geophys. Res., 2007, 112, F04014.

Rosser NJ, Petley DN, Lim M, Dunning SA, Allison RJ (2005) Terrestrial laser scanning for monitoring the process of hard rock coastal cliff erosion. Quarterly Journal of Engineering Geology an Hydrogeology, 2005, 38, 363-375, DOI: 10.1144/ 1470-9236/05-008.

Royán MJ, Abellán A, Jaboyedoff M, Vilaplana JM, Calvet J (2013) Spatio-temporal analysis of rockfall prefailure deformation using Terrestrial LiDAR. Landslides 2013, 11, 697-709.

Russo F, Calderoni G, Lombardo M (1998). Evoluzione geomorfologica della depressione Bagnoli-Fuorigrotta; periferia urbana della citta di Napoli. Bollettino della Società geologica italiana, 117(1), 21-38.

Sacchi M, Caputo T, Esposito G, Somma R, Matano F, Caccavale M, del Vecchio U, Fortelli A, Grimaldi GM, Iuliano S, Latte Bovio G, Marino E, Di Meglio C, Minardo A, Pignalosa A, Terracciano R, Troise C, Zeni L, De Natale G (2015) Sistema integrato di monitoraggio (TCM - Tuff Cliff Monitoring) dei fenomeni di dissesto lungo il costone tufaceo di Coroglio (Napoli). Rapporti Tecnici INGV, ISSN 2039-7941 Anno 2015_Numero 309

Scarpati C, Perrotta A, Lepore S, Calvert A (2013). Eruptive history of Neapolitan volcanoes: constraints from $40 \mathrm{Ar}-39$ Ar dating. Geological Magazine, 150(03), 412-425.

Slatton KC, Carter WE, Shrestha RL, Dietrich W (2007). Airborne laser swath mapping: achieving the resolution and accuracy required for geosurficial research. Geophysical Research Letters, 34(23).

Somma R, Matano F, Marino E, Caputo T, Esposito G, Caccavale $\mathrm{M}$, Carlino S, Iuliano S, Mazzola S,
Molisso F, Sacchi M, Troise C, De Natale G (2015). Application of Laser Scanning for Monitoring Coastal Cliff Instability in the Pozzuoli Bay, Coroglio Site, Posillipo Hill, Naples. G. Lollino et al. (eds.), Engineering Geology for Society and Territory - Volume 5, DOI: 10.1007/978-3-319-09048-1_133, C Springer International Publishing Switzerland 2015 Stock GM, Martel SJ, Collins BD, Harp EL (2012). Progressive failure of sheeted rock slopes: the 2009-2010 Rhombus Wall rock falls in Yosemite Valley, California, USA. Earth Surf. Process. Landf. 2012, 37, 546561.

Sturzenegger M, Stead D (2009). Close-range terrestrial digital photogrammetry and terrestrial laser scanning for discontinuity characterization on rock cuts. Eng. Geol. 2009, 106, 163-182.

Varnes DJ (1978). Slope movement types and processes. In: Schuster RL, Krizek RJ (eds) Landslides, analysis and control, special report 176: Transportation research board, National Academy of Sciences, Washington, DC., pp. 11-33

Wheaton JM, Brasington J, Darby SE and Sear DA (2010). Accounting for uncertainty in DEMs from repeat topographic surveys: improved sediment budgets. Earth Surf. Process. Landforms, 35: 136-156. doi: $10.1002 /$ esp. 1886

Yokota S, Iwamatsu A (1999). Weathering distribution in a steep slope of soft pyroclastic rocks as an indicator of slope instability. Eng Geol 55:57-68

Young AP, Ashford SA (2006). Application of airborne LIDAR for seacliff volumetric change and beach sediment budget contributions. J Coast Res 22:307-318.

\footnotetext{
*Corresponding author: Teresa Caputo,

Istituto Nazionale di Geofisica e Vulcanologia, Sezione di Napoli Osservatorio Vesuviano, Napoli, Italy; email: teresa.caputo@ingv.it.
}

C 2018 by the Istituto Nazionale di Geofisica e Vulcanologia. All rights reserved. 